\title{
Nietzsche contra Sublimation ${ }^{\dagger}$
}

\author{
Eli I. Lichtenstein
}

\begin{abstract}
Many commentators have claimed that Nietzsche views the "sublimation" (Sublimierung) of drives as a positive achievement. Against this tradition, I argue that, on the dominant if not universal Nietzschean use of Sublimierung and its cognates, sublimation is just a broad psychological analogue of the traditional (al)chemical process: the "vaporization" of drives into a finer or lighter state, figuratively if not literally. This can yield ennobling elevation, or purity in a positive sensethe intensified "sublimate" of an unrefined original sample. But it can also yield drives that are attenuated or otherworldly, in a pejorative sense. One (but only one) kind of Nietzschean sublimation is the "translation" of drives to "imaginative and spiritual" (Imaginative und Seelische) modes of expression. I conclude that, despite certain appearances to the contrary, Nietzsche ultimately values basic drives' powerful expression, without preferring either that this occur specifically as "higher culture" or as "savage" natural impulse.
\end{abstract}

Keywords: Nietzsche, sublimation, Sublimierung, drive, Freud, civilization, culture, nature, will to power

\section{Introduction}

Many think that it is best for us to sublimate our "crude" passions and "unrefined" impulses. Here "base" sexual desires and "brute" aggressive drives are paradigmatic. Many take romantic love to be a higher form of attraction, even if they also see animalistic desire as acceptable or even valuable. And many believe that aggressive impulses are elevated when expressed less violently, as in philosophical debate or athletic competition-or even in non-competitive acts of creativity or aesthetic appreciation, like Homer's epic depiction of martial valor in the Iliad, or an audience's satisfaction in the downfall of a tragic hero. More broadly, Freud claims that "sublimation of impulse" (Triebsublimierung) is "what makes it possible for higher psychical activities, scientific, artistic or ideological, to play such an important part in civilization."1

But what is sublimation, exactly? And is it in fact better, ethically or psychologically, to sublimate one's drives? Can behavioral expressions of a drive ever be excessively sublimated?

\footnotetext{
Forthcoming in Journal of the History of Philosophy

* University of Michigan, Department of Philosophy; elicht@umich.edu

1 Sigmund Freud, Civilization and Its Discontents, 44. I have substituted 'impulse' for Strachey's 'instinct,' as a translation of Trieb. For the German text, I have referred to Freud, Das Unbehagen in der Kultur.
} 
Here I will approach these basic moral psychological questions by way of historical analysis, taking Nietzsche's account of sublimation - a plausible influence on Freud - as my focal point. ${ }^{2}$ I conclude that Nietzsche does not favor "culture" over "natural passion," or vice versa, generally speaking. Rather, he is fundamentally indifferent to the distinction. However, this radical Nietzschean stance has been obscured by existing interpretive accounts. ${ }^{3}$

Many commentators have claimed that Nietzsche views the "sublimation" (Sublimierung) of "impulses" or "drives" (Triebe) as a positive achievement, if not even as a central feature of his ethical ideal. Thus, R. J. Hollingdale claims that "the men [Nietzsche] admired were those whose will to power was strong but sublimated into creativity."4 Similarly, Walter Kaufmann argues that Nietzsche uses 'sublimation' to refer to "the actual process of the overcoming of the impulses and the kind of control [he] had in mind" as an ethical ideal-whereby strong but immoral individuals like Cesare Borgia might "acquire self-control," find less brutal modes of outlet for their impulses, and hence truly "achieve greatness." 5

Even recent commentators who have advanced more resolutely amoral interpretations tend to imply that Nietzsche takes 'sublimation' to be - at least generally speaking — a good thing. For example, Eckart Goebel suggests that "Sublimation in Nietzsche" is "an increase of power, or 'great self-control.",6 On Goebel's reading, then, "A person who sublimates becomes more powerful, lives better and more intensely, and the most powerful person is the one who best understands how to sublimate [der Mächtigste ist der, der am besten zu sublimieren versteht]."’ So too, Rüdiger Safranski associates Nietzschean sublimation with conscious life acting as

2 Regarding Nietzsche's influence on Freud, see, e.g. Richard Waugaman, "Intellectual Relationship"; Ronald Lehrer, Nietzsche's Presence; and A. H. Chapman and Mirian Chapman-Santana, "Influence of Nietzsche." These discussions are typical in noting the apparent continuity between Nietzsche's appeals to 'sublimation' and Freud's, yet without analyzing the notion in detail. For richer accounts, see, e.g. Reinhard Gasser, Nietzsche und Freud, 313-65; and Ken Gemes, "Freud and Nietzsche on Sublimation."

3 Luke Phillips may seem to defend the same thesis, but he does not—see Phillips, "Sublimation and the Übermensch." I elaborate below, but in short: Phillips claims that Nietzsche "recommend[s] sublimation," which Phillips takes to involve "translation (or transformation) of the drive's objects into the imaginative and mental," as a means to a "refined immorality" ("Sublimation and the Übermensch," 351, 360). I deny that Nietzsche ultimately privileges any "refinement" of this sort, whether moral or immoral.

4 Hollingdale, The Man and His Philosophy, 162.

5 Kaufmann, Philosopher, Psychologist, Antichrist, 224.

6 Goebel, Jenseits des Unbehagens, 87.

7 Goebel, Jenseits des Unbehagens, 87. 
"enhancing force," rather than "inhibiting" force or "anxieties, moral scruples, and resignation." John Richardson likewise claims that Nietzsche takes drives to reach a "higher or fuller power" insofar as they achieve "“sublimation' [Sublimierung]," which Richardson construes as "interepisodic" rather than "intra-episodic" growth. In (mere) "intra-episodic" growth, a drive repeatedly passes towards a fixed aim in a "cyclical form," as an "episodic rush toward its end." By contrast, on Richardson's interpretation, a drive is sublimated insofar as "instead of trying just to eat or seduce again and again, it ... raise[s] its whole pattern of effort 'to a higher level,", such that it "break[s] habitual patterns and evolve[s] new forms." Richardson also indirectly relates sublimation to psychic integration, invoking cases where "A drive is 'sublimated' and made to express itself by weaving itself as an ongoing thread in a larger project." ${ }^{10}$ In turn, Ken Gemes interprets Nietzschean sublimation directly in terms of a similar kind of unifying subordination of "weaker" drives to "stronger" or "master" drives. According to Gemes, that is, "Sublimation is what happens when a drive's primary aim is substituted for by a secondary aim that allows for expression of the drive in a manner consonant with the master drive." " Gemes thus argues that Nietzsche takes sublimation to be "the key means" to the "concerted" expression of drives, and "hence, to overcoming ressentiment."12

But while these accounts of Nietzschean sublimation are in many ways helpful, they are nevertheless quite problematic. Nietzsche does praise the forms of "inter-episodic growth" and psychic "integration" that Richardson and Gemes insightfully examine. He does value the "expansion of power," which he views as the aim of "the really fundamental instinct of life" (GS

\footnotetext{
Safranski, Philosophical Biography, 321.

Richardson, Nietzsche's System, 25.

Richardson, Nietzsche's System, 120.

Gemes, "Freud and Nietzsche on Sublimation," 48.

12 Gemes, "Freud and Nietzsche on Sublimation," 48. Note that Gemes does not claim that sublimation always yields an "overcoming of ressentiment." See also Richard Schacht, Nietzsche, 370-71; and Joseph Swenson, "Sublimation and Affirmation." Cf. Paul-Laurent Assoun, Freud and Nietzsche, 161-62; and Gasser, Nietzsche und Freud, 361-64.
} 
349). ${ }^{13}$ And he does speak highly of achieving certain forms of "self-control." ${ }^{14}$ But none of these are what Nietzsche means by the term 'sublimation' (Sublimierung) orand its cognates, in many important cases. ${ }^{15}$ On the dominant if not universal Nietzschean usage, rather, for a drive to be sublimated is just for it to be figuratively if not literally "vaporized," as in the chemical transition from a solid to a gaseous state. ${ }^{16}$

One (but only one) salient form of psychological "vaporization," for Nietzsche, is the "translation" of drives from bodily or sensuous to "imaginative and spiritual [Imaginative und Seelische]" modes of expression (GM II.7). ${ }^{17}$ This is loosely related to Freudian accounts of sublimation, as the redirection of drives from sexual to non-sexual aims. ${ }^{18}$ But the present notion is broader, insofar as sexual desire is just one among many "sensuous" drives. Thus, Nietzschean sublimation also includes phenomena like expressing a "drive to cruelty" aesthetically, by creating or enjoying tragic drama, rather than physically-which is not to say sexually. ${ }^{19}$ And whereas Freud takes sublimation to be crucial to psychic health, Nietzsche is critical of its role (in certain cases) in attenuating our primal drives.

Here it is helpful to distinguish two interrelated concepts of sublimation. First,

13 In citations to Nietzsche's published works and the notes collected in The Will to Power, Arabic numerals referring to section numbers follow abbreviations of the title of the work cited. E.g. GS 349 is The Gay Science, Section 349. When works are divided into volumes, parts, or chapters, across which sections are not numbered consecutively, Roman numerals or abbreviations of chapter titles precede section numbers. E.g. GM II.7 is On the Genealogy of Morals, Essay II, Section 7; HH "Wanderer," 181 is Human, All Too Human, "The Wanderer and His Shadow," Section 181; and TI "Skirmishes," 10 is Twilight of the Idols, "Skirmishes of an Untimely Man," Section 10. For some notes collected in The Will to Power, I also indicate the year(s) in which Nietzsche wrote them inside square brackets following the section number, e.g. WP 123[1887]. For some notes, I instead cite the Kritische Studienausgabe of Nietzsche's Sämtliche Werke edited by Giorgio Colli and Mazzino Montinari (KSA), by volume and fragment number. I follow the Kaufmann and Hollingdale translations for all of Nietzsche's published works and unpublished notes, except where stated otherwise. For the German text of all of Nietzsche's published works and unpublished notes, I have referred to the Digitale Kritische Gesamtausgabe (eKGWB) edited by Paolo D'Iorio, which is based on the Kritische Gesamtausgabe edited by Colli and Montinari (KGW).

14 E.g. consider his appeal to "the self-control and fascination of strength" (WP 123[1887]).

15 Gemes only claims that his account is "in line with many of [Nietzsche's] uses of that term" ("Freud and Nietzsche on Sublimation," 56n16). Our accounts are thus compatible, insofar as we stress different Nietzschean uses. However, see n. 23.

16 I briefly address the question of whether Nietzsche might intend at least some of his psychological extensions of this (al)chemical notion of sublimation to be taken literally, rather than figuratively, below.

17 Here I have substituted 'spiritual' for 'psychical,' as a translation of Seelische.

18 E.g. Freud says that sublimation "consists in the instinct directing itself towards an aim other than, and remote from, that of sexual satisfaction" (Complete Psychological Works, 94). See also Frances Deri, "On Sublimation."

19 Compare BGE 229 - although Nietzsche here uses Erhaben for 'sublime.' I discuss this issue further below. 
'sublimation' can denote figurative elevation, with connotations of ennoblement. Second, 'sublimation' traditionally denoted (al)chemical processes related to "subtilization," whereby solid matter is vaporized or dispersed into an airier or finer, hence lighter and often purer, substance. The first sense is essentially a figurative extension of the second: "vaporized" substances rise upward, which can be viewed as a metaphor for (or a mark of) their ennoblement.

The central concept underlying most, if not all, of Nietzsche's uses of Sublimierung and its cognates is just a broad psychological analogue of the second, chemical concept: the vaporization of drives - whether it be merely figurative, or at times perhaps more closer to literal. ${ }^{20}$ One (but only one) specification of this broad psychological analogue of the chemical notion of sublimation, and one thatwhich Nietzsche invokes at times, is the ennobling "elevation" of a drive-for example, via ritual purification that yields a refined "sublimate" drive. A distinct specification of the same broad psychological analogue of chemical sublimation, which he also sometimes invokes, is a drive's "translation" from bodily or sensuous to "imaginative and spiritual" modes of expression. In short, then, Nietzsche emphasizes different features or connotations of the same basic chemical process of sublimation in different rhetorical contexts, as he extends this chemical notion of "vaporization" to the psychological domain by analogy. Hence, he sometimes (but not always) uses 'sublimation' to refer to what he views as decidedly ignoble processes of psychic vaporization, especially via the attenuation or otherworldly idealization of drives.

The common belief that imaginative and spiritual expressions of drives are "higher" is unduly moralistic, Nietzsche thus sometimes claims - even as he also often praises apparently "refined" forms of artistic and intellectual expression. By working to reconcile this apparent tension, we can better grasp the complex relation between Nietzsche's critique of JudeoChristian morality and his own positive vision of spiritual "elevation." $\mathrm{He}$ is often precisely concerned to show how one kind of sublimation, involving the attenuating vaporization of drives into the imaginative and spiritual domain, runs counter to higher forms of will to power or self-

20 See n. 16. 
overcoming. Still, basic drives often can manifest in their full force as culture, or as refinement into culture. But Nietzsche ultimately values the powerful expression of basic drives, without preferring either that this occur specifically as "higher culture" or as "savage" natural impulse.

\section{On Sublimation as Negative}

Before delving more deeply into the chemical analogy underlying most, if not all, of Nietzsche's appeals to psychological 'sublimation,' it will first be helpful simply to establish that he sometimes uses the term to characterize phenomena that he views negatively, in a way that clearly limits the applicability of common interpretations. We may begin with a remark from Human, All Too Human: "We know vanity [die Eitelkeit] only in its feeblest [abgeschwächtesten] forms, in its sublimations and small doses [in ihren Sublimirungen und kleinen Dosen], because we live in a late and very moderated [sehr gemilderten] state of society" (HH "Wanderer," 181). ${ }^{21}$ Nietzsche's broader point is that in "primeval conditions [Urzustände]" of insecurity and hunger, a "powerful person [Mächtige]" who is also "cunning [listig]" realizes that "when the fear he engenders increases, his power increases," and so develops a (vain) drive to "augment belief in his power." Thus, while we now see it only in its "feeblest forms," vanity was once "the most useful of all things" forto those aiming at power ( $H H$ "Wanderer," 181).

Here 'sublimation' evidently has little to do with "admirable" channeling of will to power into creativity (contra Hollingdale); nor with "greatness" achieved through "self-control" (contra Kaufmann); nor with "becoming more powerful" or "living more intensely" (contra Goebel); nor with "enhancing force" (contra Safranksi); nor with an "inter-episodic growth" of drives which yields their "fuller or truer power" (contra Richardson);22 nor with psychic "integration" achieved by weaving a drive into a larger project or subordinating a "weaker" drive to a "stronger" one, in a way that is a "mark of health" (contra Gemes). ${ }^{23}$ Rather, Nietzsche here

${ }^{21}$ I have substituted 'moderated' for Hollingdale's bowdlerizing 'ameliorated,' as a translation of gemilderten.

22 Richardson, Nietzsche's System, 25.

23 Gemes claims that "Nietzsche, like Freud, takes sublimation as a mark of health" ("Freud and Nietzsche on Sublimation," 47). To be sure, it is not fair to expect Gemes's account to capture all Nietzschean uses of 'sublimation,' and perhaps not even most of them- he never claims to do so. Notably, however, Gemes does not attempt to present any quotations in which Nietzsche uses the term 'sublimation' in a way that supports his own 
associates sublimation directly with "small doses" and the moderation or attenuation of a basic impulse. $^{24}$

Clearly, then, Nietzsche does not take sublimation (at least in this sense) to essentially involve "greater satisfaction for [a given] drive," as has been suggested by Luke Phillips, a recent commentator who emphasizes Nietzsche's occasional associations of 'sublimation' with the "imaginative or mental" expression of drives. ${ }^{25}$ Phillips does acknowledge Nietzsche's appeal to "sublimations and small doses," and that this use stands in tension with his own interpretation of Nietzschean sublimation as essentially involving "augmentation of the [sublimated] drive's power." 26 But Phillips argues that this is just an "exception" to Nietzsche's "later and more developed use" of the term, both on the grounds that it is "a relatively early use of the word" in his corpus and because he is "seldom careful with his terms and definitions." 27

However, if another salient interpretive hypothesis readily accommodates passages like this one, then interpretive charity speaks in favor of avoiding a quick appeal to lack of care or precision, on Nietzsche's part. Moreover, his pejorative use of 'sublimation' in this passage is neither an "exception" nor even restricted to his early works. In Beyond Good and Evil, for

interpretation. (Gemes does mention GM II.7 and KSA 12:254 in a footnote, but does not maintain that these uses are compatible with his account — indeed, he acknowledges that the second is not ["Freud and Nietzsche on Sublimation," 56n16]. These are the only two Nietzschean uses of Sublimierung or its cognates that he mentions.) This is evidently because Gemes is interested in the contrast between (what he calls) 'sublimation' and 'repression,' not in Nietzsche's use of certain words. This is fair, and Gemes provides an illuminating analysis of Freud, Nietzsche, and their interrelation. But Gemes does claim that his account is "in line with many of [Nietzsche's] uses of that term [Sublimieriung]" ("Freud and Nietzsche on Sublimation," 56n16) - yet he does not textually support this claim.

24 One might object that it is not fair to attribute to Gemes the view that Nietzschean sublimation is essentially a matter of integrating drives into a broader psychic whole; nor the view that Nietzsche takes sublimation always to serve this end. (I am grateful to an anonymous referee at the Journal of the History of Philosophy for pressing me on this point.) However, note that Gemes must take Nietzschean sublimation to essentially involve a certain kind of psychic integration or unity, insofar as he analyzes it directly in terms of a given subordinate drive's primary aim being substituted for by a secondary aim that allows this drive to be expressed in a manner consonant with a corresponding master drive ("Freud and Nietzsche on Sublimation," 48). Thus construed, the sublimation of a drive essentially involves its integration into the activity of a "master" drive to which it is subordinated ("Freud and Nietzsche on Sublimation," 48). That said, not all such instances of local psychic integration amount to the holistic psychic unity of a coherent subject. I therefore do not mean to impute to Gemes the view that Nietzschean sublimation essentially involves or inevitably results in a robustly unified individual, coherent subject, etc.

25 Phillips, "Sublimation and the Übermensch," 350. Here, recall also Safranski's association of Nietzschean sublimation with "enhancing force" (Philosophical Biography, 321).

26 Phillips, "Sublimation and the Übermensch," 351.

27 Phillips, "Sublimation and the Übermensch," $364 \mathrm{n} 25$. 
instance, he argues that "with the help of a religion which indulged and flattered the most sublime herd-animal desires [den sublimsten Heerdenthier-Begierden], we have reached the point where we find even in political and social institutions an ever more visible expression of this morality: the democratic movement is the heir of the Christian movement" (BGE 202). Indeed, even the connotations of moderation or attenuation from the earlier passage on "sublimations and small doses" of vanity are here plausibly retained. In an unpublished note from 1885, for example, Nietzsche appeals to "the total mollification of the democratic herd animal [die gänzliche Vergutmüthigung des demokratischen Heerdenthieres]" (WP 125).

This usage of 'sublime' (sublimsten) does not fit any better with Richardson's or Gemes's accounts. Again, Richardson claims that Nietzsche believes that a given drive "should try to raise its whole pattern of effort 'to a higher level," and "calls this truer, 'inter-episodic' growth 'sublimation' [Sublimierung]." ${ }^{28}$ According to Richardson, then, a drive that does not achieve sublimation therefore "misses a fuller or truer power." ${ }^{29}$ Richardson's use of both the normative term 'should' and the evocative phrase 'fuller or truer power' suggests that Nietzsche takes sublimation to be a positive achievement. ${ }^{30}$ But this is far from clearly the case in $B G E 202$.

Indeed, Nietzsche evidently does not think that herd-animal desires "should" be sublimated into democratic politics, or that they thereby achieve a "fuller or truer power." Likewise, he clearly does not believe that political impulses should "weave themselves as ongoing threads" into herd-morality construed as a "larger project." Nor is it plausible that Nietzsche believes the "Christian movement" should "evolve" into the "democratic movement," which he clearly disdains. For instance, he claims that "the advent of democracy" is one of the

28 Richardson, Nietzsche's System, 25.

29 Richardson, Nietzsche's System, 25.

30 Further, more or less directly after analyzing 'sublimation' in terms of "inter-episodic growth," Richardson claims that "a drive wills power by trying to develop its activity pattern," where "each such activity pattern wills its own 'self-overcoming' [Selbstüberwindung]: it wills to rise toward a new and higher level of effort ... one that will then have to be overcome in turn" (Nietzsche's System, 26). In turn, Richardson identifies will to power as Nietzsche's basic standard of value (see, e.g. Nietzsche's System, 152). It seems that sublimation is thus (for Nietzsche) good, on Richardson's account, insofar as he takes drives' willing power or self-overcoming to be good. Note that Richardson still need not claim that all instances of sublimation are equally good, however, insofar as he allows that there are "degrees of realization of the will to power" (Nietzsche's System, 142). See also Richardson, "Nietzsche's Value Monism." 
"symptoms of declining life" that "always means something is wrong" (GM III.25). He elaborates elsewhere that "the democratic movement is not only a form of the decay of political organization but a form of the decay, namely the diminution, of man, making him mediocre and lowering his value" (BGE 203). ${ }^{31}$ To be clear: Nietzsche does plausibly believe that the "democratic movement" is a "sublimated" form of the "Christian movement."32 But this sublimation of Christianity into democratic politics is not something that Nietzsche views as good - not that he takes the prior "Christian movement" to be any better. Contra Gemes, then, in this case it is not true that "Nietzsche, like Freud, takes sublimation as a mark of health." 33

Several other textual examples will help to drive this point further home. First, consider Nietzsche's rhetorical question about the impact of "European Christianity": “doesn't it seem that a single will dominated Europe for eighteen centuries - to turn man into a sublime miscarriage [eine sublime Missgeburt]?" (BGE 62). He then proceeds to lament "this almost deliberate degeneration and atrophy of man represented by the Christian European" (BGE 62). This is hardly the rousing endorsement of the "sublime" that common interpretations of Nietzschean Sublimierung might lead one to expect. Indeed, when he refers approvingly to the "sublime self-conquest [erhabenen Selbst-Bezwingung]" of higher types later in the same section, Nietzsche no longer even uses the Latinate root sublim-. Later in Beyond Good and Evil, likewise, he refers to the "objective man [der objektive Mensch]" as "an instrument, something of a slave though certainly the most sublime type of slave [die sublimste Art des Sklaven], but in himself nothing" (BGE 207). Finally, consider Nietzsche's harsh criticism of a certain kind of condescending indifference towards religion that he associates with "the great majority of industrious scholars and the other accessories of the universities":

On the basis of [a German scholar's] whole trade . . . he is inclined toward a

31 See also $B G E$ 44, 242; $T I$ "Skirmishes," 38-39; WP 125, 217, 728, 751, and 752.

32 This is a natural political analogue of his famous epistemological claim that "Christian conscience" has been "translated and sublimated [sublimiert] into a scientific conscience, into intellectual cleanliness at any price" (GS 357; GM III.27).

33 Gemes, "Freud and Nietzsche on Sublimation," 49. See n. 23 above. 
superior, almost good-natured amusement in the face of religion, occasionally mixed with a dash of disdain for the "uncleanliness" of the spirit which he assumes wherever a church is still acknowledged. . . . The practical indifference toward religious matters into which he has been born and brought up is generally sublimated [sublimiren] in him into caution and cleanliness [Behutsamkeit und Reinlichkeit] that shun contact with religious men and matters; and it may be precisely the depth of his tolerance and humanity that bids him dodge the subtle distress involved in tolerance. . . [H]ow much naïveté, venerable, childlike, and boundlessly clumsy naïveté lies in the scholar's faith in his superiority, in the good conscience of his tolerance, in the unsuspecting simple certainty with which his instinct treats the religious man as an inferior and lower type that he has outgrown, leaving it behind, beneath him-him, that presumptuous little dwarf and rabble man, the assiduous and speedy head- and handiworker [der kleine anmaassliche Zwerg und Pöbelmann, der fleissig-flinke Kopf- und Handarbeiter] of "ideas," of "modern ideas"! ( $B G E 58)$

Nietzsche claims that "practical indifference towards religious matters" is often "sublimated" into a "caution and cleanliness" that actively shuns them. But the result is clearly not "selfcontrol" or "creativity" in any "admirable" sense (contra Kaufmann and Hollingdale), or the praiseworthy "evolution" of this sublimated practical indifference (contra Richardson). This process of sublimation clearly does not yield "overcoming of ressentiment," on Nietzsche's view, nor is it a "mark of health" (contra Gemes). ${ }^{34}$ Rather, it produces only a "presumptuous little dwarf and rabble man," who wrongly believes himself to be superior to the religious man.

Apparently, Nietzsche is here playing on a spatial metaphor commonly associated with sublimation, namely, that of elevation or being raised up. The scholar merely takes himself to have risen above the religious believer, Nietzsche intimates. This common association of the

34 See n. 23. 
sublime with feelings of transcendence or "elevation" in turn reflects the etymology of the term, in both Longinus's Greek (hypsos, literally "height," from húpsi ["aloft," "on high"]) and the Latin (sublimis, literally, "up to the limit"). Of course, the German term Sublimierung and its cognates descend etymologically from the Latin sublimis. Notably, though, German philosophy standardly deploys the alternative term Erhaben for the modern aesthetic notion of the sublime.

Philological analysis is instructive here. Cohn and Miles report, "The sublime words first entered French, as they would enter English, through books of alchemy," and only subsequently assumed the sense of "that which is placed very high" through an act of "figurative" extension. ${ }^{35}$ In French, at least, this figurative meaning was first rhetorical, referring to the "grand style," and only subsequently given the "emotional-aesthetic" meaning characteristic of modern aesthetic theory. ${ }^{36}$ German, by contrast, "did not experience the extension of the (al)chemical meaning of sublime into figurative uses." 37 Sublim- words were thus reserved for chemical concepts, in German, whereas "all aesthetic and figurative terminology is translated into native words: erhaben, erhöhen, veredeln," except in "rare" or "extraordinary" cases. ${ }^{38}$

This historical "resistance of German to the adoption of the foreign word sublime for any but a chemical vocabulary" ${ }^{\prime 3}$ constitutes prima facie evidence in favor of a more chemicallyoriented account of Nietzschean sublimation, and against the applicability of now-intuitive direct associations of sublimation with ennobling elevation. Here intuitions are easily clouded by Freudian uses of the term: "sublimation" is clearly a positive achievement, for Freudians. As Freud's friend and colleague Ernest Jones defined it, for instance, sublimation is the "deflection of the energy of a sexual impulse to a non-sexual and socially useful goal." ${ }^{40}$ This connotation of positively contributing to individual psychic health via increased sociability is not obviously part of Nietzsche's view, though. And the traditional division of labor, whereby Latinate terms were reserved for more narrowly chemical processes and native German terms for both aesthetic and

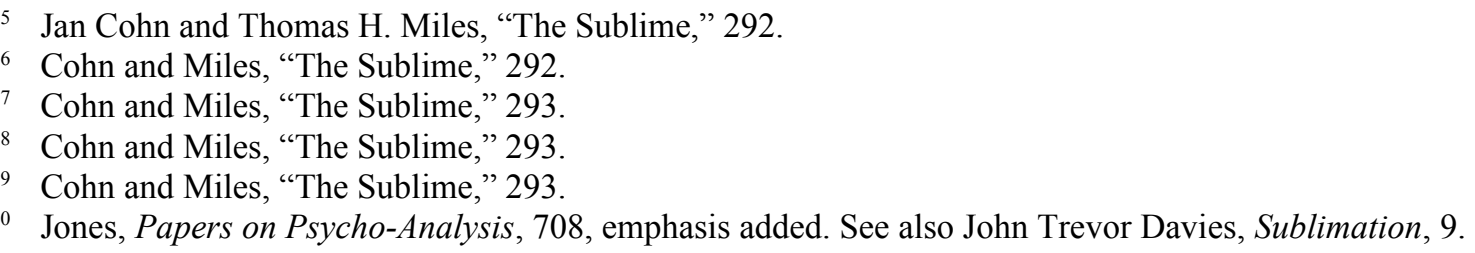


other clearly positive notions of "elevation," suggests that the strong positive valence of Freudian Sublimierung is unusual-hence, not to be quickly imputed to Nietzsche.

But did I not just claim that Nietzsche is playing on the spatial metaphor of elevation in his critical analysis of the scholar's "sublimated" practical indifference towards religious matters? And does this not presuppose that Nietzsche takes 'sublimation' to mean something like "elevation," with connotations of improvement or ennoblement, in order for an apparently ironic appeal to the scholar's "sublimated" state to have its intended rhetorical impact? This reading is limited, however, insofar as it fails to ground "elevation" in a more basic chemical notion of “vaporization." In drawing out this chemical notion's complex network of associations, it will become apparent that a broad psychological analogue of the traditional chemical sense of 'sublimation' is more central than Richardson, Gemes, and others take it to be. ${ }^{41}$ Indeed, the chemical concept of sublimation arguably underlies most, if not all, Nietzschean uses of the term. A proper reading of this chemical analogy thus has important implications for the interpretation of Nietzsche's view regarding the relative value of more and less "sublimated" expressions of drives.

\section{Elaborating the (Al)chemical Analogy}

In modern chemistry, 'sublimation' refers to an immediate phase transition from a solid into a gaseous state. The Grimms' Deutsches Wörterbuch includes references to nineteenth-century German uses of the noun sublimat ('sublimate') in a similar vein-for instance, from 1824, "chemisch das erzeugnisz jeder verflüchtigung in starrer, fester oder pulveriger gestalt." ${ }^{42}$ A sublimate is thus a solid formed by deposition from a gas that is produced through the

41 E.g. in a chapter on "Sublimierung" in his study on Nietzsche und Freud, Gasser indicates the traditional (al)chemical meaning only in passing, and this to emphasize that he will be dealing with "the psychological and not the physical concept [den psychologische und nicht den physikalischen Begriff]" (Nietzsche and Freud, 314n8). Kaufmann notes the chemical concept, but quickly proceeds to focus on Nietzsche's "new and lasting meaning," viz. drives being "channeled into creative spiritual activity, instead of being fulfilled directly" (Nietzsche, 219-20). Phillips likewise notes the basic chemical sense, but then focuses on "the connotation of simultaneous refinement and elevation, specifically in the mental or psychological realm where creativity is at its most effective" ("Sublimation and the Übermensch," 352). However, focus on this connotative nexus obscures various other Nietzschean uses of the term.

42 Jakob Grimm and Wilhelm Grimm, Deutsches Wörterbuch, art. "SUBLIMAT." 
sublimation of an original sample. Sublimates are naturally contrasted against sediments. Sublimates are solids deposited above a given sample when it is vaporized (as the resultant gas rises and re-solidifies, for instance, in the neck of an alembic), whereas sediments are solids that have settled to the bottom of a liquid mixture.

To grasp the full range of sublimation's evaluative connotations, in turn, one must note several things about this chemical process. First, it is often used to purify things: an impure sample is sublimated into a purified gas, which is then deposited as a pure sublimate of the original. Insofar as the removal of chemical impurities can in turn be associated with ritual purification, it carries positive evaluative connotations: purified sublimates can be seen as good, whereas sediments are often seen as bad — as the dregs or most undesirable part of something.

This positive evaluative connotation, of sublimation as an ennobling or otherwise valuable form of purification, underlies some of Nietzsche's uses of the term. For instance:

There have to be fasts of many kinds; and wherever powerful drives and habits prevail, legislators have to see to it that intercalary days are inserted on which such a drive is chained and learns again to hunger. Viewed from a higher vantage point, whole generations and ages that make their appearance, infected with some moral fanaticism, seem to be such times of constraint and fasting during which a drive learns to stoop and submit [ducken und niederwerfen], but also to purify [reinigen] and sharpen [schärfen] itself. . . . This is also a hint for an explanation of the paradox: why it was precisely during the most Christian period of Europe and altogether only under the pressure of Christian value judgments that the sex drive [Geschlechtstrieb] sublimated [sublimirt] itself into love [Liebe] (amourpassion). (BGE 189)

Here Nietzsche identifies love as a "sublimated" sex drive, and directly associates this process with ritual fasting that allows a drive to "learn again to hunger [wieder einmal hungern lernt]." 
Notably, this appeal to askesis does not simply concern the praiseworthy subordination of a weaker drive to a stronger one-although Nietzsche's apparently favorable reference to drives learning to "stoop and submit" is quite plausibly interpreted in this spirit, apparently in line with Gemes's account. Rather, Nietzsche's central focus seems to be on how "constraint and fasting" can allow a drive to "learn to purify and sharpen itself [aber auch such reinigen und schärfen lernt]." Likewise, he elsewhere claims that "solitude is a virtue for us" insofar as it involves a "sublime bent and urge for cleanliness [ein sublimer Hang und Drang der Reinlichkeit]" (BGE 284), and appeals to the "sublime inclination [sublime Hang] of the seeker after knowledge" who has "hardened and sharpened [gespitzt] his eye for himself" (BGE 230). My account readily explains these passages: Nietzsche consistently uses 'sublimation' in the sense of the same basic chemical analogy, and in certain cases specifically emphasizes the link between chemical sublimates and states of ritual purification.

Notably, this kind of "purification" and "sharpening" evidently need not involve psychic integration of the sort that Gemes emphasizes directly, and Richardson indirectly highlights. Psychic integration, in the sense of redirecting a weaker drive to modes of expression that render its activity more "consonant" with a stronger drive, may be one way to produce a purified "sublimate." And it may hence constitute one kind of "sublimation," for Nietzsche — albeit still not necessarily the main kind, let alone the only one. But this is arguably not what Nietzsche has in mind in $B G E$ 189. For here it is precisely "powerful [mächtige]" drives, not weaker ones, that Nietzsche claims must at times be ritually "sublimated." Evidently, this is because powerful drives are often not "hungry," insofar as they are strong enough to "prevail" and realize their ends. Hence, once must fast to artificially induce "hunger" in a powerful drive, which presumably allows it to become even stronger or more intensified in concentrated pursuit of its now-scarce end. It is therefore not at all apparent that Nietzsche envisions the sublimated sex drive as being redirected towards a secondary end that is more in line with a master drive, as on Gemes's account. While Nietzsche does appeal to "legislators" and to the "pressure" exerted on the sex drive by "Christian value judgments," it is nevertheless far from clear that he takes the 
sex drive to be thereby rendered subservient to these legislators or Christian value judgments, as Gemes's account would suggest. Rather, Nietzsche's basic point is that love is a purified and intensified form of the sex drive, produced via ritual askesis, which is hence analogous to a chemical sublimate refined from an impure original sample.

Second, and for my purposes even more importantly, sublimation transforms substances from more solid into airier or more ethereal states. This is the relevant sense of the term in Milton's Paradise Lost, for instance, when an angel describes to Adam how "flow'rs and their fruit, Man's nourishment," are "by gradual scale sublimed" into animal and ultimately intellectual "vital spirits." 43 The angel in turn hopes that "Time may come when . . f from these corporal nutriments perhaps / Your [viz. humans'] bodies may at last turn all to spirit, / . . a and winged ascend / Ethereal as we." 44 This second aspect of the chemical analogy in turn has two evaluatively salient components. Airy substances float, rise, or elevate. And airy substances are (it is said) more like mental or spiritual substance than like bodily or natural substance.

In cases where Nietzsche emphasizes the former connotation of elevation or loftiness, his uses of Sublimierung or its cognates unsurprisingly tend to be positive in tone. For instance:

Love one's enemies? I think this has been learned well: it is done thousands of times today, in small ways and big ways. Indeed, at times something higher and more sublime [Höhere und Sublimere] is done: we learn to despise when we love, and precisely when we love best. ( $B G E 216)$

There is a defiance of oneself of which many forms of asceticism are among the most sublimated expressions [sublimirtesten Aeusserungen]. . . . Thus a man climbs on dangerous paths in the highest mountains so as to mock at his fears and trembling knees. (HH I.137)

43 Book V, lines 479-90 (John Milton, Paradise Lost, 119).

44 Book V, lines 493-99 (Milton, Paradise Lost, 120). 
The bad conscience is an illness, there is no doubt about that, but an illness as pregnancy is an illness. Let us seek out the conditions under which this illness has reached its most terrible and most sublime height [furchtbarsten und sublimsten Gipfel]. (GM II.19)

The attainment of this goal [viz. "to wed the bad conscience to all the unnatural inclinations, all those aspirations to the beyond, to that which runs counter to sense, instinct, nature, animal, in short all ideals hitherto, which are one and all hostile to life and ideals that slander the world," and thus to "let ourselves go" like all the world"] would require a different kind of spirit from that likely to appear in this present age: spirits strengthened by war and victory, for whom conquest, adventure, danger, and even pain have become needs; it would require habituation to the keen air of the heights, to winter journeys, to ice and mountains in every sense; it would require even a kind of sublime wickedness [sublimer Bosheit], an ultimate, supremely self-confident mischievousness in knowledge that goes with great health; it would require, in brief and alas, precisely this great health! (GM II.24)

This praise of "sublime" elevation or loftiness is in keeping with Nietzsche's frequent celebration of levity and laughter, as well as his corresponding criticism of "gravity" or ponderousness. In Thus Spoke Zarathustra, representatively: "I laugh in your faces with my laughter of the heights" ( $Z$ "On the Tarantulas"). Likewise: "Not by wrath does one kill but by laughter. Come, let us kill the spirit of gravity! I have learned to walk: ever since, I let myself run. I have learned to fly: ever since, I do not want to be pushed before moving along. Now I am light, now I fly, now I see myself beneath myself, now a god dances through me" ( $Z$ "On Reading and Writing"). ${ }^{45}$

45 See also BGE 193; $Z$ “On the Spirit of Gravity"; $Z$ “On Old and New Tablets," 2; and GS 327, 380. By contrast, "Lack of gravity" is by contrast associated with weakness in WP 46; but here "gravity" clearly has connotations 
Note that I am not claiming that 'sublimation' and 'sublime' denote only figurative elevation or loftiness in the above passages. But they evidently do have this meaning, among several others all grounded in the same chemical notion of vaporization and applied in the psychological context by analogy. It would be grasping at straws to seek out appeals to psychic integration, self-control, or creativity in all such passages. Nietzsche's appeal to men "tyrannizing over certain parts of their own nature" in $H H$ I.137 does arguably suggest a kind of psychic integration, as Gemes's account would suggest. But this is exceptional, not typical. Nietzsche consistently just has in mind the basic chemical notion of vaporization and emphasizes different of its features in different rhetorical contexts. Figurative "elevation" is one such feature. And psychic integration - in the sense of redirecting weaker drives towards modes of expression that render their activity consonant with stronger drives - is one way to reach an "elevated" state, on his view. But it is still just one way to do so. While Nietzsche does value some kinds of psychic integration, self-control, and creativity, excessive emphasis on these phenomena obscures his many critical uses of Sublimierung or its cognates and distorts his generic praise of spiritual elevation.

Finally, the most significant cases of Nietzschean 'sublimation,' for my purposes, are those in which he emphasizes the second connotation of airiness or ethereality mentioned above: proximity to the spiritual rather than natural domain, or to mind as opposed to body etc. This is related to the spatial metaphor: the heavenly domain of "spiritual" beings is often depicted as located above the merely "natural" world. Here recall Milton's angel hoping that humans may one day "turn all to spirit, / . . and winged ascend / Ethereal as we." Differences in density or solidity are salient in this context, insofar as spiritual substance is taken to rise because it is rarefied or less dense than "coarse" matter. Milton's usage also echoes that of the earlier English poet John Davies, who in his Nosce Teipsum (1599) praises how the Mind "turnes Bodies to spirits":

of cohesion rather than heaviness. 
[...]by sublimation strange ;

As fire conuerts to fire the things it burnes,

As we our meats into our nature change.

From their grosse matter she abstracts the formes,

And drawes a kind of quintessence from things ;

Which to her proper nature she transformes,

To bear them light on her celestiall wings :

This doth she, when, from things particular,

She doth abstract the universall kinds. (Complete Poems, 43) $)^{46}$

Davies thus celebrates sublimation construed as a path to universal essence or intelligible form.

So too, Nietzsche sometimes uses 'sublimation' with a broadly similar emphasis on the mental:

Today, when suffering is always brought forward as the principal argument against existence, as the worst question mark, one does well to recall the ages in which the opposite opinion prevailed because men were unwilling to refrain from making suffer and saw in it an enchantment of the first order, a genuine seduction to life. . . Perhaps the possibility may even be allowed that this joy in cruelty [Lust an der Grausamkeit] does not really have to have died out: if pain hurts more today, it simply requires a certain sublimation and subtilization, that is to say it has to appear translated into the imaginative and spiritual ${ }^{47}$ [Imaginative und Seelische] and adorned with such innocent names that even the tenderest and most hypocritical conscience is not suspicious of them ("tragic pity" is one such name; "les nostalgies de la croix" is another). (GM II.7)

46 See also Stanton J. Linden, Darke Hierogliphicks, 93-94. The typographical errors in this quotation are in the original.

47 Here I have substituted 'spiritual' for 'psychical,' as a translation of Seelische. 
One crucial Nietzschean psychological analogue of chemical vaporization, then, is the "translation" of drives to more "imaginative and spiritual" modes of expression. Notably, Nietzsche also arguably suggests that "pain today hurts more" not in spite of the "sublimation and subtilization" of human "joy in cruelty," but if anything because of it. I will return to this point shortly below, in section 4 .

In the meantime, and in light of the above analysis, it is reasonable to wonder whether at least some of Nietzsche's appeals to 'sublimation' might involve literal (or perhaps quasi-literal) extensions of chemical processes to the psychological domain, rather than merely a chemical metaphor. ${ }^{48}$ This is not implausible, prima facie, insofar as attention to real structural analogies between chemical and psychological processes could be in keeping with broader naturalistic currents in Nietzsche's philosophy. In fact, some commentators have argued that Nietzsche's appeal to a "chemistry of concepts and sensations [Chemie der Begriffe und Empfindungen]" in the first section of Human, All Too Human is to be taken quite literally. ${ }^{49}$ Indeed, Nietzsche himself insists in this section, "Historical philosophy ... can no longer be separated from natural science [der Naturwissenschaft];" he then proceeds to diagnose "unegoistic action" and "disinterested contemplation" as "only sublimations [Sublimirungen], in which the basic element seems almost to have dispersed and reveals itself only under the most painstaking observation," before more broadly calling for "a "chemistry of the moral [eine Chemie der moralischen]", religious and aesthetic conceptions and sensations" (HH I.1). I wish to remain agnostic with respect to this further interpretive issue, however. For here I wish only to establish that the chemical concept underlies most if not all Nietzschean uses of 'sublimation'-whether his psychological extensions of the chemical notion are meant literally or figuratively.

Thus, in most, if not all, cases where he uses Sublimierung or its cognates, Nietzsche

48 I am grateful to an anonymous referee at the Journal of the History of Philosophy for stressing this point.

49 E.g. consider Christine Blättler's claim that "Nietzsche's references to chemistry cannot be reduced to the British metaphor of mental or spiritual chemistry [nicht auf die Metapher der mentalen oder geistigen Chemie der Briten reduzieren]" ("Chemie der Begriffe," 168n72). Here Blättler is approvingly citing Aldo Lanfranconi, Nietzsches Historische Philosophie, 107-15. See also Assoun, Freud and Nietzsche, 161. Regarding Nietzsche's "chemistry of concepts and sensations," see also Peter Heller, "Chemie der Begriffe." 
apparently has in mind the same basic chemical concept of vaporization, and simply emphasizes different of its features in different rhetorical contexts. Sometimes he places special emphasis on the purity of a chemically-refined sublimate. Sometimes he stresses the elevation or lightness of vapors. Sometimes he emphasizes the ethereality of "vaporized" substances, perhaps especially in connection to the "translation" of drives into the "imaginative and spiritual" domain. And he sometimes - but not always - deploys multiple of these analogical associations at once.

While the above discussion has highlighted the variety and nuance of Nietzsche's appeals to 'sublimation,' a few rough trends in his evaluative attitude towards different features of the basic psychological analogy to chemical vaporization can perhaps now be distilled. Nietzsche often presents the purification of drives positively, especially insofar as it can involve intensification. And he often presents lightness or elevation positively, while remaining critical of a certain kind of otherworldly loftiness. Relatedly, as I will now argue, Nietzsche's appeals to the ethereality or airiness of "spirit" as opposed to "nature" are quite mixed in tone-because he does not favor "higher culture" over unrefined "natural passion," or vice versa, generally speaking.

\section{Evaluating the "Imaginative and Spiritual"}

On Nietzsche's view, the common belief that more "imaginative and spiritual" ways of expressing drives are higher is unduly moralistic - even though Nietzsche himself often praises apparently "refined" forms of artistic and intellectual expression. This is not a contradiction on his part, however, insofar as he also praises more "savage" expressions of basic drives. In short, Nietzsche values the powerful expression of basic drives in one way or another more than he prefers either that they be sublimated into "culture" or given primal outlet as crude "animal impulse."

Here we may first recall Nietzsche's claim in GM II.7 that "joy in cruelty" has not really died out, but rather just been "translated" into "imaginative and spiritual" forms like "tragic pity." Notably, Nietzsche does not advocate or recommend that "joy in cruelty" be thus 
sublimated. He does not criticize the earlier age in which men "were unwilling to refrain from making suffer and saw in it an enchantment of the first order, a genuine seduction to life." Nor does he glorify this earlier age above that of sublimated tragic pity. He simply claims that they both express the same "joy in cruelty" — which evidently allows that they may do so to the same extent, and with equal value. ${ }^{50}$

This interpretation of GM II.7 can be reinforced by examining another similar passage:

In late ages that may be proud of their humanity, so much fear remains, so much superstitious fear of the "savage cruel beast" [wilden grausamen Thiere] whose conquest is the very pride of these more humane ages, that even palpable truths remain unspoken for centuries, as if by some agreement, because they look as if they might reanimate that savage beast one has finally "mortified" [abgetödteten]. ... We should reconsider cruelty and open our eyes. We should at long last learn impatience lest such immodest fat errors keep on strutting about virtuously and saucily, as have been fostered about tragedy, for example, by philosophers both ancient and modern. Almost everything we call "higher culture" [höhere Cultur] is based on the spiritualization of cruelty, on its becoming more profound [der Vergeistigung und Vertiefung der Grausamkeit]: this is my proposition. That "savage animal" [wilde Thier] has not really been "mortified"; it lives and flourishes, it has merely become-divine [vergöttlicht].

What constitutes the painful voluptuousness of tragedy is cruelty; what seems agreeable in so-called tragic pity [sogenannten tragischen Mitleiden], and at bottom in everything sublime, up to the highest and most delicate shudders of

50 Insofar as "cruelty" remains the basic underlying aim of both "sublimated" tragic pity and "unsublimated" drives to "make suffer," Richardson is right to insist that "ends are modified, not replaced" in these sorts of processes of Nietzschean sublimation (Nietzsche's System, 25n20). Thus the "basic element [Grundelement]" that is "dispersed [verflüchtigt]" and so "reveals itself only under the most painstaking observation" in a given process of "sublimation" might well be a drive to cruelty ( $H H$ I.1), rather than a fully generic will to power or drive to self-overcoming. However, my basic account is also compatible with the view that a generic will to power or drive to self-overcoming is the ultimate Grundelement of all "sublimation" of drives into the "imaginative and spiritual" domain. 
metaphysics, receives its sweetness solely from the admixture of cruelty. . . $[E] v e n$ the seeker after knowledge forces his spirit to recognize things against the inclination of the spirit, and often enough also against the wishes of his heart ... and thus acts as an artist and transfigurer of cruelty. (BGE 229)

Nietzsche does not say that he prefers "higher culture" or the "divine" version of the "savage animal." Rather, his basic point seems to be that the "savage animal" and "higher culture" alike express the same underlying drive to cruelty.

Kaufmann is thus wrong to claim that Nietzsche exalts "sublimated" states of self-control above "unsublimated animal passion." 51 Nietzsche has no problem with "unsublimated animal passion." He does not glorify it, insofar as he also values certain forms of "higher culture." But he also does not claim that it is worse than "higher culture," generally speaking. And he explicitly criticizes "superstitious fear" of the "savage cruel beast." Here one might also note Nietzsche's description of the Dionysian as one of two fundamental art-impulses, even though it manifests as a drive towards ecstatic identification with "titanic" and "barbaric" forces of nature (BT 4) that are often overtly "savage." Nietzsche's Dionysus enjoys all "productive and destructive force," evidently without concern for its moral quality (WP 1049 [1885-1886]). ${ }^{52}$

Phillips likewise observes that Nietzsche "clearly did admire and praise [ruthless and violent men like Cesare Borgia and Napoleon] and hold them in far higher esteem than he did innocent, merely moral, herd-like men who lived blameless lives." ${ }^{53}$ Indeed, Kaufmann himself concedes this point, citing $B G E$ 197: "Nietzsche found it ridiculous to consider a Cesare Borgia unhealthy in contrast to an emasculated man who is alleged to be healthy." But again, Kaufmann thinks that Borgia would be better if he achieved "sublimation": "A man with strong impulses might be evil because he had not yet learned to sublimate his impulses, but if he should ever

51 Kaufmann, Philosopher, Psychologist, Antichrist, 225.

52 See also WP 1050[1888].

53 Phillips, "Sublimation and the Übermensch," 359, but also 358-60; Paul Glenn, "Nietzsche's Napoleon"; and Don Dombowsky, Nietzsche's Machiavellian Politics. Cf. Philippa Foot, "Nietzsche’s Immoralism." 
acquire self-control, he might achieve greatness." ${ }^{54}$ Phillips is more skeptical that Nietzsche envisions any moralized form of self-control as an ethical ideal. Here I agree with Phillips, contra Kaufmann.

But Phillips is wrong to claim that Nietzsche "recommends sublimation"-which Phillips takes to essentially involve "translation (or transformation) of the drive's objects into the imaginative and mental" 55 _ and the "refined immorality" that it produces. ${ }^{56}$ Here he cites a passage in $B G E 23$, the relevant portion of which is Nietzsche's claim that "even a doctrine of the reciprocal dependence of the 'good' and the 'wicked' drives, causes (as refined immorality [feinere Immoralität]) distress and aversion in a still hale and hearty conscience — still more so, a doctrine of the derivation of all good impulses from wicked ones" (BGE 23). But this is simply a claim about the psychological impact of his own "doctrine of the derivation of all good impulses from wicked ones"- let alone the weaker "doctrine of the reciprocal dependence of the 'good' and 'wicked' drives" that he actually explicitly calls 'refined immorality.' Nietzsche does not claim here that his own ethical doctrine is better than "unrefined" forms of will to power. He at most observes that his own philosophical doctrine is "refined." And he clearly believes that his own doctrine is good. But he never claims that it is better than more "unrefined" expressions of similarly-powerful drives. More broadly, Nietzsche certainly seems to favor Goethe over Borgia. And this is clearly not because Borgia is more "evil." But it is also not at all clear that it is because Goethe is more "refined." Phillips hence fails to see how radical Nietzsche's view truly is. Nietzsche does not "recommend" that drives augment their power specifically via redirection into the "imaginative and spiritual" domain. He simply recommends will to power.

Nietzsche accepts that the translation of drives into the "imaginative and spiritual" domain can be valuable, but he also clearly believes that it can be degenerate. For instance, consider his critical assessment of (all but "genuine" ${ }^{57}$ ) philosophers as "advocates who resent

\footnotetext{
54 Kaufmann, Philosopher, Psychologist, Antichrist, 224.

55 Phillips, "Sublimation and the Übermensch," 351.

56 Phillips, "Sublimation and the Übermensch," 360.

57 For "Genuine philosophers," Nietzsche claims, " "knowing' is creating ... [and] will to truth is — will to power" (BGE 211).
} 
the name":

They all pose as if they had discovered and reached their real opinions through the self-development of a cold, pure, divinely unconcerned dialectic . . . while at bottom it is an assumption, a hunch, indeed a kind of "inspiration" - most often a desire of the heart that has been filtered and made abstract [ein abstrakt gemachter und durchgesiebter Herzenswunsch] - that they defend with reasons they have sought after the fact. They are all advocates who resent that name, and for the most part even wily spokesmen for their prejudices which they baptize "truths" - and very far from having the courage of the conscience that admits this, precisely this, to itself; very far from having the good taste of the courage which also lets this be known, whether to warn an enemy or friend, or, from exuberance, to mock itself. $(B G E 5)^{58}$

Nietzsche here explicitly suggests that philosophical theories are often rooted in "a desire of the heart that has been filtered and made abstract"-which strongly evokes his aforementioned appeal to the "sublimation" of primal "joy in cruelty" into "imaginative and spiritual" modes of expression. But he also claims that this sublimation into philosophical "dialectic" is often cowardly, hence presumably often worse than unsublimated forms of unapologetic "advocacy." 59

Many other philosophers and artists take the transformation of "crude" nature into more "imaginative and spiritual" phenomena to be inherently valuable, of course, which can promote a corresponding misinterpretation of Nietzsche. This is clearly Milton's view, for instance. And a similar sentiment appears in Goethe's autobiography, Dichtung und Wahrheit-which Nietzsche

58 See also GS 352, where Nietzsche criticizes moralists for trying to make the "profound mediocrity, timidity, and boredom" of the "herd animal" seem "nobler" and "more important" by presenting it in a spiritualized mode.

59 Compare Assoun's claim that "from Daybreak to On the Genealogy of Morals, Nietzsche never does anything else but try to outwit the process of sublimation [construed as converting the Grundelement of 'instinct as selflove' into a 'mask (of altruism)']" (Freud and Nietzsche, 161-62). Assoun's account is limited insofar as he ignores various other kinds of "vaporization" of drives, including some by "translation" into the "imaginative and spiritual" domain, which Nietzsche clearly endorses strongly, and also refers to as 'sublimation.' 
does seem to have read. ${ }^{60}$ (More generally, Goethe certainly had a strong positive influence on him. $\left.{ }^{61}\right)$ Goethe deploys a related metaphor, using hot air balloons instead of chemical vapors:

True poetry announces itself thus, that, as a worldly gospel, it can by internal cheerfulness and external comfort free us from the earthly burdens which press upon us. Like an air-balloon, it lifts us, together with the ballast which is attached to us, into higher regions and lets the confused labyrinths of the earth lie developed before us as in a bird's-eye view. The most lively, as well as the most serious works, have the same aim of moderating both pleasure and pain by a felicitous intellectual form. (From My Life, 505) ${ }^{62}$

Here Goethe links "true poetry" to "intellectual form" that "lifts" us up from "earth" and its "burdens which press upon us." Two features of his view are especially noteworthy, in the present context.

First, Goethe contrasts the domain of "intellectual form" against a lower "earthly" order, which suggests an elevation of the spiritual-intellectual above the merely natural. And, indeed, he elsewhere claims that "human feelings and events" could not be brought upon the stage "in original naturalness [ursprünglicher natürlichkeit]," but rather "must be wrought, prepared, sublimated [verarbeitet, zubereitet, sublimirt]." ${ }^{\prime 3}$ Thus Goethe contrasts "sublimated" human feeling, implicitly tied to "true poetry" and "intellectual form," against states of crude "naturalness." Notably, Emerson expresses a similar idea using a chemical analogy, in his 1836 essay on "Nature," when he characterizes art as "nature passed through the alembic of man." ${ }^{\prime 4}$ In

60 Thomas H. Brobjer, Nietzsche's Philosophical Context, 78.

${ }^{61}$ See, e.g. Kaufmann, Philosopher, Psychologist, Antichrist, 154-56 and 167-70; Barker Fairley, "Nietzsche and Goethe"; Nicholas Martin, "Nietzsche's Goethe"; Paul Bishop and R. H. Stephenson, Friedrich Nietzsche and Weimar Classicism; Adrian Del Caro, "Nietzsche and Romanticism."

62 See also Goebel, Beyond Discontent, 6.

63 Grimm and Grimm, Deutsches Wörterbuch. I follow Kaufmann's translation (Philosopher, Psychologist, Antichrist, 219). Note that Schopenhauer likewise ties 'sublimation' to intellectual forms, describing representations (Vorstellungen) being "sublimated into abstract concepts [die zu abstracten begriffen sublimirten]" (Grimm and Grimm, Deutsches Wörterbuch, art. 'SUBLIMIEREN').

64 Ralph Waldo Emerson, Essays and Lectures, 18-19. Regarding the depth of Emerson's impact on Nietzsche, 
particular, he brings out the aforementioned connotations of purification or refinement, claiming, "The poet, the painter, the sculptor, the musician, the architect, seek each to concentrate this radiance of the world on one point." ${ }^{65}$ Likewise, in a later essay on "Art," Emerson notes how good painters omit "the details, the prose of nature" so as to "give us only the spirit and splendor," and even describes man himself as "but a finer and compacter landscape than the horizon figures." ${ }^{\circ 6}$

Nietzsche holds certain related views, but he nevertheless does not view "higher culture" as generally superior to "savage" or "wild" states. In the case of "Genuine philosophers," for instance, Nietzsche insists that "knowing" is creating . . . [and] will to truth is-will to power" (BGE 211). In the case of "genuine" philosophers, that is, the impulse "to assimilate the new to the old, to simplify the manifold, and to overlook or repulse whatever is totally contradictory [das gänzlich Widersprechende]" is not an unconditional or selfless pursuit of truth. Rather, it expresses the "spirit's power to appropriate the foreign" precisely by "retouching and falsifying the whole to suit itself," its drive to "growth, in a word-or, more precisely, the feeling of growth, the feeling of increased power" ( $B G E$ 230). Thus, genuine philosophers' creative appropriation of reality in systematically "falsifying" bodies of theory is, for Nietzsche, a mode of artistic representation, which "simplifies the manifold" and "overlooks" or "repulses" any "contradictory" features of the world, as a kind of purification or refinement of "un-falsified" nature. And here just as elsewhere, presumably, "We possess art lest we perish of the truth" (WP 822). ${ }^{67}$ Indeed, Nietzsche strikes a similar chord in reflecting on art in another unpublished note from 1888, where he characterizes "The ugly [Das Häßliche]" as "the contradiction to art [der Widerspruch zur Kunst]" and "that which is excluded from art [das, was ausgeschlossen wird von der Kunst]" (WP 809). Like Emerson, then, Nietzsche does seem to view genuine art (and artistic philosophy or science) as something like "nature passed through the alembic of man."

But Nietzsche does not view this kind of artistic "distillation" into truly higher forms of

see, e.g. Brobjer, Nietzsche's Philosophical Context, 23.

65 Emerson, Essays and Lectures, 18.

66 Emerson, Essays and Lectures, 431.

67 There is no mention of science in this context, so I am quoting quite freely. 
"imaginative and spiritual" culture as being better than "savage" or "wild" nature, per se, because he allows that there are also higher forms of the purely "savage" or "wild." For instance, in The Birth of Tragedy, Nietzsche speaks approvingly of the origin of the tragic chorus in cultic Dionysus-worshipers raising themselves into a state of ritual frenzy through collective song and dance. In the resultant state of ecstasy, the "chorus of primitive tragedy" found themselves "liv[ing] in a religiously acknowledged reality under the sanction of myth and cult," experiencing the world as transformed into a "fictitious natural state" and themselves as likewise "magical[ly] transform[ed]" into a chorus of "satyrs" or "fictitious natural being[s]" (BT 7) embodying man's "highest and most intense emotions" and "Nature, as yet unchanged by knowledge, with the bolts of culture still unbroken" (BT 8). Of course, Nietzsche values many forms of "higher culture," including later Attic tragedy insofar as it involves a complex fusion of "Dionysian" and "Apollonian" tendencies. Nevertheless, he also clearly values certain forms of "savage" or "wild" nature. And it is far from clear that "high cultural" forms are his favorite expressions of our basic drives. In The Birth of Tragedy, Nietzsche does arguably privilege tragedy, viewed as the "objectification of a Dionysian state" into its "Apollonian complement" (BT 8), above either purely Dionysian or Apollonian modes of activity. But Nietzsche later criticized his own youthful romanticism in this book, and in particular his call for an "art of metaphysical comfort" (BT 18). The older Nietzsche associates this drive to "metaphysical comfort" with romanticism and Christianity, and instead recommends learning "the art of thisworldly comfort first" (BT "Attempt at a Self-Criticism," 7). Part of what is at stake here, evidently, is whether the "primordial contradiction and primordial pain in the heart of the primal unity" that Nietzsche associates with Dionysian insight into reality (BT 6) needs to be "redeemed" through "falsifying" Apollonian dream-images. Nietzsche's mature view is that it does not: pure Dionysian frenzy or "destruction of individuality" is a fully valuable mode of will to power in its own right — albeit not the only one.

Translation into the more ethereal, "imaginative and spiritual" domain can involve valuable forms of purification and intensification, on Nietzsche's view. But "higher culture" can 
also be polluted by "impurities," and be attenuated or unduly otherworldly. Nietzsche speaks of sublimation approvingly when he uses the term Sublimierung to refer to intensifying purification. But he does not map valuable processes of "purification" directly onto the processes of translation into the "imaginative and spiritual" domain that he also refers to using the term 'sublimation.' These are two distinct applications of the same basic chemical analogy-even though in some cases Nietzsche does view development from "savage" to "high cultural" expressions of drives as a source of intensifying purification, à la Emerson.

Finally, Goethe specifically praises the intellectual "elevation" afforded by "true poetry" as a way of "moderating both pleasure and pain." This evokes Freud's later account of sublimation:

Another technique for fending off suffering [Leidabwehr] is the employment of the displacements of libido [Libidoverschiebungen] which our mental apparatus permits of and through which its function gains so much in flexibility. The task here is that of shifting the instinctual aims [Triebziele] in such a way that they cannot come up against frustration from the external world. In this, sublimation of the instincts [Sublimierung der Triebe] lends its assistance. One gains the most if one can sufficiently heighten the yield of pleasure [Lustgewinn] from the sources of psychical and intellectual [psychischer und intellektueller] work. When that is so, fate can do little against one. A satisfaction of this kind, such as an artist's joy in creating, in giving his phantasies body, or a scientist's in solving problems or discovering truths, has a special quality which we shall certainly one day be able to characterize in metapsychological terms. At present we can only say figuratively that such satisfactions seem "finer and higher" [feiner und höher]. But their intensity is mild [gedämpft] as compared with that derived from the sating of crude and primary instinctual impulses [grober, primärer Triebregungen]; it does not convulse our physical being. (Civilization and Its 
Discontents, 26-27)

For Freud as for Goethe, sublimation of natural drives into intellectual or artistic-creative modes of expression functions to protect us from excessive pain and is valuable in this respect. For both thinkers, moreover, sublimation of natural feeling or impulse leads to a moderation of pleasure. Goethe evidently views this moderating effect as positive. Freud's characterization is more ambiguous, but also seems broadly positive: he apparently thinks that it is appropriate or healthy to avoid the "jarring" impact of "crude and primary impulses." Here note that Freud's only direct criticisms of sublimation, in this broader passage, are that it is "accessible to only a few people," and that even to them it "cannot give complete protection from suffering [vollkommenen Leidensschutz]." ${ }^{98}$

Goethe's and Freud's approving emphasis on the moderating effect of the translation of natural feelings or impulses into the "imaginative and spiritual" domain is almost directly opposed to Nietzsche's view, insofar as he takes this particular kind of sublimation to be praiseworthy. Thus, Nietzsche writes in a note from 1888 that "the effect of works of art is to excite the state that creates art-intoxication [Rausch; alternately, 'frenzy']" (WP 821). ${ }^{69}$ And, as he clarifies in another note from 1888, this "condition of pleasure called intoxication" is "precisely an exalted feeling of power" (WP 800). On Nietzsche's view, Apollonian and Dionysian art forms therefore both elicit a state of "intoxication" ( $T$ I"Skirmishes," 10). Although he does associate the Apollonian with "extreme calm," he qualifies that Apollonian Rausch still involves "sexuality and voluptuousness," and even clarifies that this "extreme calm" is "more strictly" to be viewed as "the retardation of the feelings of time and space" (WP 799). Thus, insofar as Nietzsche takes some processes of translation into the "imaginative and spiritual" domain to be valuable, it is clearly not because he thinks that they involve the moderation of our drives. Quite the opposite: he claims that "All art works tonically, increases

${ }_{68}$ Freud, Civilization and Its Discontents, 27.

69 Nietzsche sometimes uses Rausch in a narrower sense. In The Birth of Tragedy, for example, he maps the distinction between Apollonian and Dionysian drives onto "dreams and intoxication [des Traumes und des Rausches]" (BT 1). 
strength, inflames desire (i.e. the feeling of strength), excites all the more subtle recollections of intoxication" (WP 809). Nor does this kind of artistic intensification of our drives involve moderation of pain or pleasure, on Nietzsche's view. Here recall his claim that the translation of our basic "joy in cruelty" into the "imaginative and spiritual" domain is directly related to the fact that "pain today hurts more" (GM II.7). Likewise, in Human, All Too Human he longs for a "utopia" or a "better ordering of society" that leads "step by step up to him who is most sensitive to the most highly sublimated species of suffering [die höchsten sublimirtesten Gattungen des Leidens] and who therefore suffers even when life is alleviated to the greatest degree possible" (HH I.462).

Hence, to the extent that Nietzsche does value some (but not all) processes of translation into the "imaginative and spiritual" domain, it is precisely insofar as they intensify our basic drives, as well as associated forms of pain or joy. Correspondingly, where this form of sublimation has the opposite effect - as in lesser philosophers' pretense to "cold, pure, divinely unconcerned dialectic" or the "sublimations and small doses" of vanity in our "late and very moderated state of society"-Nietzsche evidently sees it as weak, unhealthy, and to be criticized.

Could it not be that Nietzsche most highly esteems "imaginative and spiritual" modes of outlet for powerful drives, or "high cultural" expressions of strength, vitality, etc. - even if he values "savage" expressions of power above "spiritual" expressions of weakness or sickness? In response to this question, which merits extended examination in its own right, I will here simply conclude with a few fairly modest interpretive points. First, the hypothesis that a preference for "spiritual" over "natural" forms of activity is a ceteris paribus consideration for Nietzsche-for example, a "tiebreaking" consideration to be deployed only when given "spiritual" and "natural" forms of activity reflect the same degree of underlying strength, power, health, etc. - is consistent with my basic claim that Nietzsche is fundamentally indifferent to the distinction between "nature" and "culture." The intuitive "nature vs. culture" distinction is at most a second-order concern for Nietzsche, subordinate to his more basic evaluative emphasis on

70 I am grateful to one anonymous referee at the Journal of the History of Philosophy for pressing me on this point, and to another for encouraging me to offer further concrete examples of Nietzsche criticizing sublimation. 
the strength of drives or the continual growth of their power.

Second, however, the textual case for even this limited "tiebreaker" account is hardly conclusive. For instance, as I have argued, Nietzsche uses Sublimierung to refer to a range of psychological analogues of chemical vaporization, not all of which concern the translation of drives to the imaginative and spiritual domain. Hence, while Nietzsche's positive uses of Sublimierung may appear to be clear evidence that he has a ceteris paribus preference for imaginative and spiritual outlets of drives, in fact they often are not. Moreover, while he evidently highly values many "cultural" phenomena, it is also clear that Nietzsche highly values certain purely "natural" things, including "titanic" and "barbaric" forces (BT 4). ${ }^{71}$ Relatedly, Nietzsche's narrowly ethical ideal could involve the imaginative and spiritual outlet of powerful drives even if his more basic standard of will to power does not.

In this light, finally, one might distinguish between two senses of 'culture,' on Nietzsche's behalf. On the one hand, culture can be viewed through a radically naturalistic lens, as including even manifestations of the "titanic" and "barbaric" natural forces which Nietzsche links to the creative-destructive activity of the "entirely reckless and amoral artist-god" or "artist's meaning" that he takes himself to have illuminated in The Birth of Tragedy (BT "Attempt at a Self-Criticism," 5). On the other hand, however, culture (and art) can be taken to be directly opposed to such "merely natural" phenomena. Nietzsche clearly values culture in the former, more naturalistic sense very highly. But culture in this sense evidently need not involve the translation of drives to the "imaginative and spiritual" domain, at least in any way that always "elevates" them up from "savage" and into "refined" modes of expression.

\section{Conclusion}

Existing accounts of Nietzschean sublimation tend to stress only certain of his uses of the term Sublimierung, and therefore impute a more idiosyncratic concept to him than is truly warranted.

71 Consider also Nietzsche's praise of the world as a "sea of forces flowing and rushing together" (WP 1067). It is not clear, in WP 1067, that he takes human creativity to be the "highest" such force. For similar kinds of holism with strongly naturalistic undertones, see, e.g. TI "What the Germans Lack," 49; WP 417. 
Indeed, some commentators offer little or no direct textual evidence in support of their interpretations. ${ }^{72}$ Although I have not discussed all of Nietzsche's uses of the term, I do take myself to have presented and explicated a wider range of cases than other commentators. And I have done so using a flexible interpretive framework that plausibly extends to most, if not all, other Nietzschean uses of Sublimierung and its cognates.

The central concept underlying most if not all Nietzschean uses of Sublimierung and its cognates is just a broad psychological analogue of the traditional (al)chemical concept: the "vaporization" of drives. Nietzsche emphasizes different features or connotations of chemical sublimation in different rhetorical contexts, as he extends the notion to the psychological domain by analogy. Hence, sometimes Nietzschean sublimation yields ennobling elevation, or purity in a positive sense - the intensified "sublimate" of an unrefined original sample. But Nietzschean sublimation can also yield drives that are attenuated or otherworldly, in a pejorative sense.

If this were merely a terminological issue, it would not be terribly important. But it is not. Terminological confusion on this point can easily promote conceptual confusion, and obscures important Nietzschean ideas. In particular, one might be led to seriously misunderstand the evaluative connotations of Nietzsche's uses of 'sublimation' and its cognates, if one fails to appreciate that he uses the term in several distinct ways, all stemming from a basic psychological analogy to the traditional sense of chemical vaporization. More specifically still, one might be led to seriously misinterpret Nietzsche's evaluation of the "sublimation" of drives into “imaginative and spiritual" modes of expression, if one conflates his different uses of the term.

Some other commentators have recognized that Nietzsche is skeptical of at least certain kinds of "sublimation." 73 And some have indicated the traditional chemical sense of the term in passing. ${ }^{74}$ But none have synthesized these lines of analysis by relating a wide array of both negative and positive Nietzschean uses of Sublimierung to his multivalent application of the basic chemical analogy, as I have tried to do above-with attention to the chemical notion's

\footnotetext{
E.g. regarding Gemes's account, see n. 23.

73 E.g. Assoun, Freud and Nietzsche, 161-62 (see n. 59); and Gasser, Nietzsche und Freud, 361-64.

74 E.g. Kaufmann, Phillips, and Gasser (see n. 41); also Blättler and Assoun (see n. 49).
} 
wider role in modern intellectual history. And none have suggested that the connotative complexity of the chemical notion may help to explain why it is easy to overstate how much or how clearly Nietzsche values the redirection of drives into the "imaginative and spiritual" domain.

Indeed, Nietzsche's often-neglected critical remarks about sublimation help to reveal that he does not hold sophisticated forms of artistic or intellectual creativity above "coarser" expressions of our basic drives, per se. Rather, he is often precisely concerned to show how the "vaporization" of drives into the imaginative and spiritual domain can run counter to higher forms of will to power or self-overcoming. Basic drives can manifest in their full force as culture, or as refinement into culture. But Nietzsche ultimately values the powerful expression of basic drives, without preferring either that this occur in the mode of "higher culture" or as "savage" natural impulse. ${ }^{75}$

\section{Bibliography and Abbreviations}

Assoun, Paul-Laurent. Freud and Nietzsche. Translated by Richard L. Collier. New York: Continuum, 2000.

Bishop, Paul, and R. H. Stephenson. Friedrich Nietzsche and Weimar Classicism. New York: Camden House, 2005.

Blättler, Christine. “'Chemie der Begriffe' und 'historischer Sinn.' Überlegungen zur philosophischen Begriffsbildung." Berichte Zur Wissenschaftsgeschichte 38 (2015): 15369. ["Chemie der Begriffe"]

Brobjer, Thomas H. Nietzsche's Philosophical Context: An Intellectual Biography. UrbanaChampaign: University of Illinois Press, 2008. [Nietzsche's Philosophical Context]

Chapman, A. H., and Mirian Chapman-Santana. "The Influence of Nietzsche on Freud's Ideas." British Journal of Psychiatry 166 (1995): 251-53. ["Influence of Nietzsche"]

Cohn, Jan, and Thomas H. Miles. "The Sublime: In Alchemy, Aesthetics, and Psychoanalysis." Modern Philology 74 (1977): 289-304. ["The Sublime"]

Davies, John. The Complete Poems of Sir John Davies, vol. 1. Edited by Alexander B. Grosart. London: Chatto and Windus, 1876. [Complete Poems]

Davies, John Trevor. Sublimation. New York: MacMillan, 1947.

Del Caro, Adrian. "Nietzsche and Romanticism: Goethe, Hölderlin, and Wagner." In The Oxford

75 I would like to thank Tad Schmaltz, Daniel Herwitz, and Gordon Belot for helpful discussions and advice, as well as Pavel Godfrey for a long-standing dialogue about many aspects of Nietzsche's thought, without which this paper would not have been possible. I am also grateful to two anonymous referees for their constructive feedback, and to the editorial staff at the Journal of the History of Philosophy. 
Handbook of Nietzsche, edited by Ken Gemes and John Richardson, 108-33. Oxford: Oxford University Press, 2013. ["Nietzsche and Romanticism"]

Deri, Frances. “On Sublimation.” Psychoanalytic Quarterly 8 (1939): 325-34.

Dombowsky, Don. Nietzsche's Machiavellian Politics. New York: Palgrave MacMillan, 2004.

Emerson, Ralph Waldo. Essays and Lectures. Edited by Joel Porte. New York: Library of America, 1983.

Fairley, Barker. "Nietzsche and Goethe." Bulletin of the John Rylands Library 18 (1934): 298314.

Foot, Philippa. "Nietzsche's Immoralism." In Nietzsche, Genealogy, Morality: Essays on Nietzsche's Genealogy of Morals, edited by Richard Schacht, 3-14. Berkeley: University of California Press, 1994.

Freud, Sigmund. Civilization and Its Discontents. Edited and translated by James Strachey. New York: W. W. Norton, 1962.

- Das Unbehagen in der Kultur. Wien: Internationaler Psychoanalytischer Verlag, 1930.

- The Standard Edition of the Complete Psychological Works of Sigmund Freud, vol. 14. Edited and translated by James Strachey. London: Hogarth Press, 1961. [Complete Psychological Works]

Gasser, Reinhard. Nietzsche und Freud. Berlin: Walter de Gruyter, 1997.

Gemes, Ken. "Freud and Nietzsche on Sublimation." Journal of Nietzsche Studies 38 (2009): 38 59.

Glenn, Paul F. "Nietzsche's Napoleon: The Higher Man as Political Actor." The Review of Politics 63 (2001): 129-58. ["Nietzsche's Napoleon"]

Goebel, Eckart. Beyond Discontent: 'Sublimation' from Goethe to Lacan. Translated by James C. Wagner. New York: Continuum, 2012. [Beyond Discontent]

- Jenseits des Unbehagens: 'Sublimierung' von Goethe bis Lacan. Bielefeld: transcript Verlag, 2009. [Jenseits des Unbehagens]

Goethe, Johann Wolfgang von. The Auto-Biography of Goethe. Truth and Poetry: From My Own Life, vol. 1. Translated by John Oxenford. London: Bell \& Daldy, 1867. [From My Life]

Grimm, Jakob and Wilhelm Grimm. Deutsches Wörterbuch. Leipzig: S. Hirzel, 1971.

Heller, Peter. "'Chemie der Begriffe und Empfindungen.' Studie zum 1. Aphorismus von 'Menschliches, Allzumenschliches I.”" Nietzsche-Studien 1 (1972): 210-33. [“Chemie der Begriffe"]

Hollingdale, R. J. Nietzsche: The Man and His Philosophy. Rev. ed. Cambridge: Cambridge University Press, 1999. [The Man and His Philosophy]

Jones, Ernest. Papers on Psycho-Analysis. Third ed. New York: William Wood and Company, 1923.

Kaufmann, Walter. Nietzsche: Philosopher, Psychologist, Antichrist. Princeton: Princeton University Press, 1974. [Philosopher, Psychologist, Antichrist]

Lanfranconi, Aldo. Nietzsches Historische Philosophie. Stuttgart: Frommann- Holzboog, 2000.

Lehrer, Ronald. Nietzsche's Presence in Freud's Life and Thought. Albany: State University of New York Press, 1995. [Nietzsche's Presence]

Linden, Stanton J. Darke Hierogliphicks: Alchemy in English Literature from Chaucer to the 
Restoration. Lexington: The University Press of Kentucky, 1996. [Darke Hierogliphicks] Martin, Nicholas. "Nietzsche's Goethe: In Sickness and In Health." Publications of the English Goethe Society 77 (2013): 113-24. ["Nietzsche's Goethe"]

Milton, John. Paradise Lost: A Norton Critical Edition. Edited by Gordon Teskey. New York: W. W. Norton, 2005. [Paradise Lost]

Nietzsche, Friedrich. Beyond Good and Evil: Prelude to a Philosophy of the Future. Translated by Walter Kaufmann. New York: Vintage Books, 1966. [BGE]

- The Birth of Tragedy, or: Hellenism and Pessimism. In The Birth of Tragedy and The Case of Wagner, translated by Walter Kaufmann, 15-144. New York: Vintage Books, 1967. [BT]

- Digitale Kritische Gesamtausgabe Werke und Briefe. Edited by Paolo D'Iorio. Paris: Nietzsche Source, 2009-. http://www.nietzschesource.org/eKGWB. [eKGWB]

- The Gay Science: With a Prelude in Rhymes and an Appendix in Songs. Translated by Walter Kaufmann. New York: Vintage Books, 1974. [GS]

. On the Genealogy of Morals. In On the Genealogy of Morals and Ecce Homo, edited by Walter Kaufmann and translated by Walter Kaufmann and R. J. Hollingdale, 14-198. New York: Vintage Books, 1989. [GM]

- Human, All Too Human: A Book for Free Spirits. Translated by R. J. Hollingdale. Cambridge: Cambridge University Press, 1996. [HH]

—. Sämtliche Werke. Kritische Studienausgabe, 15 vols. Edited by Giorgio Colli and Mazzino Montinari. 2nd ed. Berlin: de Gruyter, 1988. [KSA]

—. Thus Spoke Zarathustra: A Book for All and None. In The Portable Nietzsche, translated and edited by Walter Kaufmann, 103-439. New York: Penguin, 1976. [Z]

—. Twilight of the Idols, or, How One Philosophizes with a Hammer. In The Portable Nietzsche, translated and edited by Walter Kaufmann, 463-564. New York: Penguin, 1976. [TI]

- Werke. Kritische Gesamtausgabe, 30 vols. Edited by Giorgio Colli and Mazzino Montinari. Berlin: Walter de Gruyter, 1967-. [KGW]

- The Will to Power. Edited by Walter Kaufmann. Translated by Walter Kaufmann and R. J. Hollingdale. New York: Vintage Books, 1968. [WP]

Phillips, Luke. "Sublimation and the Übermensch.” Journal of Nietzsche Studies 46 (2015): 34966.

Richardson, John. Nietzsche's System. Oxford: Oxford University Press, 1996. . "Nietzsche's Value Monism: Saying Yes to Everything." In Nietzsche on Mind and Nature, edited by Manuel Dries and P. J. E. Kail, 89-119. Oxford: Oxford University Press, 2015. ["Nietzsche's Value Monism"]

Safranski, Rüdiger. Nietzsche: A Philosophical Biography. Translated by Shelley Frisch. New York: W. W. Norton, 2003. [Philosophical Biography]

Schacht, Richard. Nietzsche. London: Routledge \& Kegan Paul, 1983.

Swenson, Joseph. "Sublimation and Affirmation in Nietzsche's Psychology." Journal of Nietzsche Studies 45 (2014): 196-209. ["Sublimation and Affirmation"]

Waugaman, Richard. "The Intellectual Relationship between Nietzsche and Freud." Psychiatry 36 (1973): 458-67. [“Intellectual Relationship"] 